\title{
Women's Rights in Pakistan
}

\author{
* Muhammad Aqeel Khan, Assistant Professor (Corresponding Author) \\ ** Muhammad Zubair, Associate Professor
}

\begin{abstract}
The critically discusses the women's rights in Pakistan. For this purpose, it explores the Patriarchal nature of the society and the historical background of women's rights in Pakistan. Before it does so, the paper also throws light on the status of women in Islam and enumerates the important rights the woman holds in Islamic law because of Islam's great influence in the state of Pakistan.
\end{abstract}

Keywords: Islamization, MFLO, Patriarchy, Sharia, and Ulema.

Introduction

In all patriarchal and male-dominated societies, the women seldom have an opportunity to flourish fully and stand up for their cause; Pakistan is no exception to it. Therefore, the government of Pakistan has a long and mixed history of coping with the issue of women rights. It ratified several human rights treaties including the Convention on the Political Rights of Women in 1953. By promulgating the Muslim Family Laws Ordinance (MFLO) in 1961which regulates the marriage and restricts polygamy Pakistan went one step further than what the Convention on the Consent to Marriage, Minimum Age for Marriage and Registration of Marriage, 1962, required from member states, although Pakistan had not ratified it. Because under MFLO not only registration of marriage is essential but several protections to the wife are also available in case of divorce and or husband's second marriage.

Later on, Pakistan ratified human rights instruments e.g. UN Convention of the Rights of Child in 1990, the 1993 Vienna Declaration which equated women's rights with human rights, the 1994 Cairo Population and Development Conference's Programme of Action and the 1995 Platform for Action in Beijing. Similarly in 1996 Pakistan ratified the Convention on Elimination of All Forms of Discrimination against Women (CEDAW), which was adopted by the UN General Assembly in 1979. By ratifying CEDAW Pakistan undertook the obligation to review its laws and social institutions, to bring them into conformity with CEDAW and eliminate all forms of discrimination against women. But in the times to come little progress was made to fulfil the obligations; even the first mandatory report to the CEDAW Committee was not submitted. The Musharraf government, which came to power through a military coup in 1999, to justify his government and win the support of moderates in the country, took the issue of women's empowerment seriously. Before his government could submit Pakistan's first report to CEDAW Committee, the tragedy of 09/11 happened and the Coalition forces attacked Afghanistan. Submitting the report to the CEDAW Committee has been on hold since then. Pakistan State has been embroiled by this substantial conflict and, like its past forty years, much of the consequent social disorder has concentrated on women's rights. Mutahida Majlis-e-Amal (MMA), an electoral alliance of six religious parties won the provincial elections in 2002 in the then NWFP, Pakistan's province adjacent to war-torn Afghanistan and it further escalated the degree of conflicting visions of women's rights held by different segments of society. The current legislation by Punjab Government for the protection of women against domestic violence has once again highlighted the issue and spur a debate between traditionalists and reformists within Pakistan.

There has always been a controversy, right from the birth of Pakistan, regarding the concept of 'Human Rights in Pakistan'. There has been more controversy regarding the rights of women. The roots of democracy have weakened in the beginning itself due to unnecessary delay in the making of the Constitution and untimely demise of charismatic leaders. According to conservatives as well as

* Department of Law, Abdul Wali Khan University Mardan, Khyber-Pakhtunkhwa, Pakistan.

Email: aqeel@awkum.edu.pk

** Department of Law, Abdul Wali Khan University Mardan, Khyber- Pakhtunkhwa, Pakistan.

Email: mzubair@awkum.edu.pk 
modernists in Pakistan, the concept of Human Rights is greatly based on Western ideology. Pakistan has been of the view that in comparison to the West there is a very basic difference in the social, economic, and political conditions in Pakistan and that they cannot just break away the age-old customs and traditions in one blow disregarding the cultural and social values. It will take a long time to bring about the necessary reforms in it (Anwar, 1984).

Before understanding the condition of women in Pakistan, it is necessary to know the position of women in Islam and along with that, the role women played in the Pakistan movement. As far as the position of women in Islam is concerned it will be reasonable first to understand their position in other problems especially the legal and behavioural aspects of other civilizations. This is a wellknown fact that compared to men the condition of women has always been weak right from the beginning in all the societies. The history of human civilization proves it. The womenfolk have had to tolerate all kinds of cruelty. Instead of making her an independent individual, her condition has been reduced to a maidservant.' Whenever a girl child is born even in present society there might be extremely few progressive families who would be happy. In most of the cases, a pall of gloom descends over the family members. Birth of a girl child is deemed as a sin, a bad woman, and whatnot. A woman is projected as a commodity more than a human being the moment she steps in her youth. After having evaluated minutely the family system of almost all ancient civilizations, one can easily find out these evils in the society. Also, the condition of women has been quite weak right from the beginning even in the western civilization which itself took the responsibility of emancipating humanity from the burden of ignorance in the 19th century (Badbai, 1999).

The whole of the Arabian regions where Islam spread, was such a society, which was conferred the name of nomadic society. This nomadic society had its own rules and regulations. Especially in the case of women they had their perspective. Women were considered as mere commodities. They were in such a weak position that they could easily be bought and sold (Javid. 1998). This vicious cycle used to go on and on. Then men had an upper handover women in every issue. They were always bound to abide by the orders of either their father or husband. The women had no independent status in the social and economic matters of the family. They had no role to play even on the social level. There was also a tradition on annual occasions such as fairs; women were made to dance naked, surrounded by poets who composed poems based on the beautiful movements of their organs. In other words, it can be easily said that women were considered merely a symbol of sex. Before the establishment of Islam as mentioned in the Holy Quran, whenever the birth of a girl child was declared the faces of people present there turned pale and they looked quite troubled. The relatives of the girl child used to evade facing people after getting this news. They even debated in their minds whether they should let the girl child live or bury her alive.

The most fundamental cause behind all this was that in the nomadic Arab society before the establishment of Islam, there had been violent struggles among the neighbours. The men had the grave responsibility of protecting their kingdom. That was the reason why the demand for men was much more than women. In the nomadic struggles also women used to be the main target of attack. The enemy left no chance to kidnap the opponent's ladies and demanded heavy ransom to release them. On not being paid the money, they used to turn the women into their slaves. In both cases, the women were considered as such a burden on society, which gave birth to all kinds of social, economic, and political problems. If they gave away the money, they would be left poor, and if not the cursed women used to be raped which resulted in a great humiliation to the social image of the menfolk (Malik, 1981)

There has been no discrimination done between men and women in Islam.

Prophet Muhammad. (PBUH) has given a special place to women in Islam. His sermons found a great deal of success in doing away with age-old wrong practices that were being followed in Arab. Keeping in mind the rights of women, Prophet Mohammad (PBUH) gave religious acceptance in this regard and took a revolutionary step at par with the era that was going on. This is all the more important to know that excluding the Hindu civilization, women's rights were not supported by religious levels by any of the contemporary civilizations (Rauf, 1981).

To bring about overall development in society man and woman must develop a relationship of cooperation and rapport. Both should play the role of a friend and supporter to one another. A society can truly develop only by their mutual and sincere support and cooperation. Employing his sermons, Prophet Muhammad (PBUH) established a new phase of cordial relationship between men and 
women. This relationship was different from the man-woman relationship of the nomadic society before the establishment of Islam. This new relationship between them was based on faith, wisdom, and a special feeling of respect for the man for the woman (Maududi, 1953). From the very onset, Islam has been a staunch supporter of the fact that women constituting nearly half of the society's population should be provided with all those facilities with the help of which they can develop themselves naturally. Islam gives liberal, social, political, and economic rights to women. Islam has arranged legal remedies also so that men do not eliminate these rights of women. In principle, the following rights have been bestowed upon the Muslim women (Maududi, 1993).

\section{Right to Property}

This includes the right to manage her property in the way a woman likes. She can make any essential remedy in this regard. She can transfer her property to anyone if she wants to. Her right to property will not be affected if an unmarried woman decides to get married on her own. This economic right has been given to women in the Holy Quran especially based on the preaching of 'Zakat' (Anis, 1981).

\section{Right to Marriage and Divorce}

Islam gives a lot of importance to marriage. Marriage is considered such a union of two souls that aims to uplift and promote humanity and to achieve intellectual and emotional goodwill of one another. Islam is strictly against forcing marriage on a woman (Sayeed A. 1993). There is also a legal remedy for women in this regard. Paigamber Sahib emphasizes that in all these activities the opinion of parents will also be taken into consideration. At that time Kansa was forced by her father to marry. Kansa did not want to marry that person therefore she complained to Paigamber Sahib. Paigamber Sahib welcomed Kansa's decision to marry by her own choice and he set her free from the responsibility of marriage.

\section{Right to Education}

The right to get education by both men and women has been supported by the Quran as well asSunnah. Quran says all human beings have equal rights to seek knowledge without the discrimination of sex. It has also been said in the Quran that those who have faith and knowledge more than the others, they are very high in the eyes of Allah (Sayeed A. 1993). It has been clearly said that seeking wisdom and knowledge is the spiritual duty of every individual. That is why there is no discrimination based on sex with regards to the cost of education (Al-Hashmi, 1983)

\section{Right to Inheritance}

Islam gives women equal rights like men to inherit the property of their forefathers. It can also be legally secured by court. Quran says that both men and women have the equal right to share the property left by their fore-fathers whether the property is less or more.

\section{Political Rights}

Islam encourages women to participate in political activities so that they may contribute actively in their role of decision -making. The women have the right to argue and speak their viewpoint. They can represent any delegation of politicians. Paigamber Sahib gives a lot of importance to the decisions and advice given by women. Ayesha and Salma the two wives of Prophet Muhammad (PBUH) were the Jiving example of this. Salma was the adviser of Prophet Muhammad (PBUH) in the political matters and she also used to work as the Imam in matters related to women. Ayesha used to play an important role in the political matters of her section of society. She strongly mad a protest against the policies of the rulers and also led the groups of protesters (Rauf, 1981).

\section{Right to Honor}

Islam, apart from giving equal status to women along with men also shows a special respect to them. As said by Paigamber Sahib a Muslim will be considered a true one only if he has a special respect for his women whether she is his wife, sister, mother, daughter, and niece, or in any other relation. In his religious farewell festival, in Mount Mercy Arafat he said, give total independence to women and fear God. You have married her by God's directions and you both have gained a right over one another's body. In his whole life, Prophet Muhammad (PBUH) had struggled on a personal level for the rights of women. The Islamic society, after Prophet Muhammad (PBUH), perhaps did not follow those values to that level as desired by the Prophet. Cultures of different societies before Islam proved to be the main hindrance in this work. Even today they are posing as a hindrance before the rights of women in Islamic countries. This has been the reason why different Islamic countries have different levels of respect for the rights of women (Mehreen G. 1988). On one hand, there is Turkey, an Islamic country, where women are given almost as much freedom as in western society. In the middle level, 
we have Indonesia, where women are given reasonable freedom. And another third and final level, we have countries like Pakistan, Iran, and Afghanistan, where despite Islamic instructions the orthodox elements have influenced the decision-making bodies in the opposite direction to a great extent and thus have negatively affected its practical implementation (Rauf, 1981).

\section{Creation of Pakistan and Women's Rights}

Quaid-e-Azam nJinnah immediately after getting freedom on 14 August 1947, started to lead the nation in the direction of a progressive, liberal and democratic country. He formed a Constituent Assembly to prepare the Constitution of the country. In his famous words;

"No nation can rise to the height of glory unless their women are side by side with them...It is a crime against humanity that our women are shut up within the four walls of the houses as prisoners. There is no sanction anywhere for the deplorable condition in which our women have to live." (Jinnah, 1948).

This Constituent Assembly had to create such a Constitution upon which a strong foundation for progressive, liberal, and democratic Pakistan could be laid, Jinnah heavily stressed upon it at a personal level. But Jinnah mostly remained ill after freedom. He died in September 1948. Taking advantage of Jinnah's death the orthodox elements again started raising their ugly heads and started strong resistance for the creation of an Islamic state in Pakistan. On initial stage, Jinnah had turned down the Ahrar Movement, Barelvi and Deobandi religious center's demand for an Islamic state. It is noteworthy that though the orthodox factions had differences on other matters but on the matter of suppressing the rights of women and keeping them under the veil and boundaries almost all of them were one.

Liaqat wanted to create a Pakistan where people had freedom of speech and expression, freedom of conscience, freedom of women's rights, human dignity and tolerance without any discrimination. He also believed that establishing a democratic system was in line with the Islamic provisions as it will benefit to the common Muslim citizen. Under the leadership of Liaqat, the politicians of that time too stressed much upon the Islamic principles. Due to the Islamic majority, the Muslims had no danger in Pakistan socially or religiously for this was to be apprehended (Hamid K. 2001).

On the other hand, the orthodox elements stressed more upon Islamic laws. They especially stressed that as the philosophical basis of the Pakistan Movement was Islam therefore all systems in Pakistan should be according to the Quran and Sunnah. In this system, it has to be the work of Ulema to oversee the actual implementation of Islamic laws. Ulema should have the right to interpret the Islamic provisions from their angle. Because of the changing need of times, orthodox elements were hell-bent to provide a weak position to women and minorities in their proposed Islamic State. Amidst this ideological debate, the Prime Minister Liaqat Ali Khan put his famous 'Objective Resolution' for consideration on 4 March 1949.

The people of all ideologies were given a representation in it. The board invited Syed Suleman Naqvi from Lucknow to take its membership. This board submitted its report on 11 April 1950 to the -sub-committee related to the Constitution and its distribution of power. Though this subcommittee turned down the recommendation of the Talimat-e-Islamic Board. The basic Principal Committee submitted an interim report in August, 1950 which was opposed by Ulema of all branches. This report had originally repeated the provisions of the Government of India Act 1935 and advised that all Muslims must study the Quran. Maulana Abul Ala Maududi, who was the founder of Jamaate-Islami opposed this report and termed it as an effort of the creation of a secular state (Winder L. 1961). The report was taken back under the pressure of Ulema.

Liaqat Ali Khan appealed the Ulema to send their constructive suggestions to the committee. To stress upon the concept of Islamic State the Ulema organized a convention in Lahore in 1951. In this convention, they passed a proposal to create the Constitution according to Islamic provisions where the right of interpretation was with Ulema, all provisions were to be according to the spirit of Islamic and Sunnah and the state should not have the right to take back any Islamic ordinance. The Ulema organized another convention in 1953.

Maududi was a native of Hyderabad (Andhra Pradesh, India), Syed Qutub and Maududi are considered authentic interpreters of the Sunni branch while Ayatullah Khomeini of Shia branch. This also a fact that Sunnis are in a majority globally in comparison to Shias. Thus, despite the convention of 1935 and 1953 of Ulema and their proposals Maududi stressed heavily upon the provisions of 
Islam. Maududi cleared that in an Islamic state voting rights should be given only to the adults and educated women. He also postulated that women were not to be appointed in such offices where they could come in the contact with other men. He also announced that all-important official posts which included state head and executive head were to be given to males only (Maududi 1978). He advocated a Separate Assembly of women, which could s suggest the legislature on the issues related to women. Maududi and other Ulema made their full attempt both inside and outside the Constituent Assembly that the proposed Constitution (Constitution of 1956) was based upon Islamic provisions, especially upon the system of the Quran and Sunnah and its right of interpretation should also be confined with to Ulema alone (Maududi, 1993).

In the initial years, the leaders did not give much heed to the orthodox elements and kept working on their appeasement also. For instance, as per their demand, Pakistan was declared an Islamic Republic by the Constitution of 1956. The Ulema were given the role of advisers in the legislative. Though many of their demands like-restricting women from contesting elections, creation of a separate ministry for religious matters, separate electoral system for Muslims and non-Muslims were turned down by Constituent Assembly. Despite this, the Ulema gave recognition to the Constitution of 1950 as an Islamic Constitution. By the time, a new government could be formed through new elections, according to the provision of 1956, the contemporary Army head General Ayub khan captured power in October 1958. Ayub banned all the political parties. Ayub strongly opposed orthodox thought of the Ulema and declared them the main obstacle in the way of society's progress. Ayub put many Ulema behind the bars. In 1963, he sentnced Maulana Maududi to jail. Ayub also removed the namesake word Islami while introducing his Constitution of 1962 and declared Pakistan as a Republic. Ayub kept the Ulema in the advisory committees to advice according to Islamic ideology but refused to give them the right to examine the quality of Islamic laws. He also established a Central Islamic Research Institute whose aim was to take away the right of interpreting the Islamic provisions from the orthodox Ulema (Dawn 1980).

Ayub Khan strongly hated the reactionary and orthodox elements. Ayub believed that their retrogressive ideas were responsible to keep the society in its backward state. Ayub underlined the contribution of women in the development of society. The women were given relatively significant liberty. Ayub's attacks on orthodox elements helped women's rights also. Ayub particularly issued the Family Law Ordinance of 1961 for women. This ordinance was mainly based on the suggestion of Justice Rashid Commission. Justice Rashid was the Chief Justice of Apex court at that time. The Commission had given more progressive suggestion, which had explained those causes upon which divorce could be sought in Court.

Though such provisions have already adopted in other Muslim countries like Tunisia, Turkey, and Iran, this ordinance met strong opposition from Ulema who declared it completely nonIslamic. The religious leaders exhorted their followers to launch a movement against this throughout the country learning it opposing the Quran. The women too began their countrywide campaign against the Ulema. Begum Naseem Jahan led the opposition in Lahore. The effigy of Maulana Abbas Ali Khan who was the chief opponent of the ordinance in East Pakistan was burnt in the rally (Qazi S. 1999). Apart from this too, there are many provisions in this ordinance in support of women's rights. Though this ordinance did not end overnight the bitterness between husband-wife relations prolonged but this brought confidence among women which proved inspiring in their further struggle for their rights.

Maulana Maududi was angry with Ayub's actions upon the Ulema. He attempted a political coalition with the leader of East Pakistan Suhrawardi to fight Ayub politically. He talks about creating a common front against Ayub that began in October 1962. Here it is very important to mention that Suhrawardi was a secular leader. Suharawardi did not accept any principles of Jamaat-e-lsami and had openly criticized Maududi in 1956. Suharawardi had well known for his non-Islamic ideas among the followers of Jamaat-e-Islami. Not only this when in the elections of 1964 the joint opposition declared Fatima Jinnah the sister of Quaid-e-Azam as the presidential candidate. Taking support of the Islamic groups moved this discussion again that Islam did not give women the right to achieve the highest post. Interestingly Ayub brought many Ulermas to his side using the power of wealth and managed them to deliver statements against Fatima Jinnah. Though he could win the Ulemas, he could not get the support of Maulana Maududi, the guardian of Islam in Pakistan who had earlier voiced women as unfit for being elected to the highest post. 
As Ayub had subjected them to tortures variously apart from jailing them, Maududi and other prominent Ulema supported Fatima Jinnah in the presidential elections of 1964. To take avenge them, not only this Maulana Maududi, who was in jail at that time, wrote a letter for deliberating the burning question of political empowerment of women to the council of Ulema and asked them to support Fatima Jinnah. This proposal of Maududi was passed without any amendment (Niaji K. 1974).

The election of 1964 proves it. The Prophet of Islam Mohammad Sahib had declared that the feet of women in heaven and had supported their equality with men on every step. In 1969, the military rule of Yahya Khan came after Ayub. Thereafter Zulfiqar Ali Bhutto became the President and he also enforced the Constitution of 1973. At the time of Zulfiqar Bhutto's assuming of power, the morale of the army along with bureaucracy was low. Zulfiqar Ali Bhutto had contested in the general elections of 1970 on the slogan of Islamic Socialism and promised the people the basic amenities of roti kapra aur Makan, for the first time in the history of Pakistan. The people had believed that the glittering crown of power could be a real achievement of a popular leader. A majority of society especially the lower class had very enthusiastically voted in this election. Right after its formation in 1967, Pakistan People's Party had attracted many intellectuals towards it in the initial years-where there were not only males but there were a remarkable number of females also. Not only, the young women voted for the PPP in large numbers but also brought the common people to polling stations and also stopped the irregularities, which could have happened at the polling centers. The untiring labor of women had a great impact on the victory of the PPP in all areas of Pakistan. Begum Naseem who was also a founder member of the PPP had organized women in Lahore on large scale. All the rights of women were included in the election Manifesto of the PPP. It had promised to ensure equality of women with men. After the election, those women volunteers, who had played a very active role in the elections, were given good posts in the committees. Most of the women volunteers had direct interaction with the women of the weaker sections of the society. There was a special experience for those women who came from the joint families and were almost ignorant of the problems of women of this section. Due to the pressure of women and Bhutto's commitment to women's rights, the women were given maximum rights by the Constitution of 1973 than in all the constitutions made till date. Article 25 of 1973 Constitutions provided equal rights to all the citizens. Women were given special attention with this guarantee that there should be no gender-based discrimination with them. Similarly, Article 27 guaranteed equal opportunity to women in government, services without any discrimination. Article 32 provided for the reservation of seats for women in the election of local bodies. Article 34 guaranteed emancipation of women from all sorts of discrimination in life. Section 35 guaranteed the women marriage and family system and other liberties. Section 228 provided that at least one woman will be included in the proposed Islamic ideology council.

The Bhutto Government adopted many other means apart from these provisions which gave pace to the otherwise loose movement for women empowerment. For the first time Rana Liaqat Ali Khan (wife of former P.M. Liaqat Khan) became the Governor of Sind. Another woman Kaniz Fatima was made Vice-Chancellor of a University. One more women Ashraf Abbasi was chosen the Vice President of the National Assembly. Through the administrative reforms of 1972, women were given entrance into government jobs.

For the first time Women were allowed entry into Foreign Service that was earlier banned on practical ground. The World Women's year of 1975 was celebrated with much enthusiasm. Begum Nusrat Bhutto became the representative of Pakistan in the Mexico Conference on Women and Pakistan signed on the Mexico Declaration of Women's Rights (VR and Sans, 1941). In January 1976, a thirteen member Women Rights Commission was established. The Attorney General of Pakistan Yahya Bakhtiyar was its President. Nine women members were included in this Commission. The Commission was given the responsibility to study the condition of the women in Pakistan and submit its report to the government. The Commission was given the task of contemplating upon the projects to improve the social, economic and legal condition of women and suggest such measures under which effective investigations could be done of the atrocities against woman, issues of maintenance, custody of the child, divorce etc. could be looked into and also suggest measures to eradicate these evils (Dawn, 1976).

This committee gave its report in July 1976. Due to Bhutto's removal from power on 5 July 1977 neither it received the acceptance of legislative nor were they enacted in any manner. Politically 
also the PPP created a national cell for women. Before this, Ayub also contributed enormously to bring women on the equal footing with men in the matters of marriage, divorce and family matters through the Family Law Ordinance of 1961. But Zulfiqar Ali Bhutto had made very serious efforts to empower women in every field of life.

Mr. Zia imposed Martial Law in July 1977. The political parties were banned. Bhutto was first sent to jail and then sentenced to death. This had extensive reaction worldwide along with this illegal regime of Zia had been facing crisis to establish the validity of his regime. General Zia did not only use the name of Islam to prove legality to his illegal regime unlike all other former Pakistani rulers, he proclaimed his very aim to introduce the policy of Islamisation or Nizam-e.-Mustafa in the country. For the first time in Pakistan, he gave direct representation to Islamic parties in power. Due to this, the Islamic groups consolidated their position where they had been discredited till now. The Islamic orthodox elements started to act as the guardian and visionary of Zia's Nizam-e-Mustafa programme. The orthodox elements had expressed their opposition against women rights during the formation of 1956 Constitution itself by interpreting the Islamic provisions in their own ways. With their support, Zia for the first time got the golden opportunity to directly enact them. In this regard the orthodox elements made laws by amending 67 articles out of total 280 in the 1973 Constitution tried to convert the women second grade citizen.

On 10 Feb. 1979, Zia enacted the Hudood Ordinance, which was his first strong attempt of lslamisation. This ordinance was mainly responsible for the pathetic condition of women. Despite being in the $21^{\text {st }}$ century and continuance of democratic government from 1988-99 this ordinance still stands. This ordinance was originally passed by the British in 1937 itself but due to sustained pressure it could not have been enacted. General Zia enacted Qanoon-e-Shahadat on October 1984. According to this, the testimony of two Muslims woman would treated equal to one Muslim male (Goldjear I. 1981). It was for Zina earlier. The minority male is equal to a Muslim woman, while in this regard the minority women are half even to their own males. The adverse use of Hudood Ordinance is made in the cases against love marriages. The case of Kanwar Ashan and Rifat Afridi is one such example. Both had a love marriage. Both belong to different clans. The relatives accused that their daughter was forcibly kidnapped. Later On, the group of Afridi wounded Ahsan with gunshot in the court premises itself. Afridi and Ahsan were accused of illegal sexual relations. Afridi spoke clearly that her relationship was Pious. Islam allows it since they had a love marriage. Somehow they were freed from punishment. General Zia pleased his orthodox masters by enacting Hudood and Kanoon-e-Shahadat laws against women. In 1982, he appointed Ansari Commission to give suggestions as how to create an ideal society according to Islam and especially the women's place in it. Ansari Commission gave many suggestions opposing women's empowerment. The main among them were a ban on women becoming state head. The women should attain the age of 50 to be a member of Shura or legislative (which is 25 years only in case of male) prohibition to women going abroad without a male guardian or unmarried women joining foreign services, ban on women participating to sports activities held publicly (Al-Hashmi, 1983).

The orthodox elements tried their utmost to apply these provisions in the entire country with the active support of the state. Due to military rule the women organisations of Pakistan could not put their strong opposition of those black laws against woman. During this, the government of western countries expressed formal disapproval while at the same time, they were helping with weapons and money since they were against the coming of the Communism. Still the women have risen quite much from the conditions of Zia's era and today they can express themselves freely at least in towns. Asma Jehangir and her sister Hina Jeelani have given much momentum to the Women's Right Movement practically. President Pervez Musharraf held the general elections in 2002. Seats for women in National as well as Provincial Assemblies were reserved. Different political parties could introduce this reservation in proportion to their votes received in the elections. Due to this system the representation of women in National Assembly of Pakistan has increased to 21.6 per cent today in the world of 21 st century.

The civil society is still in its infancy. In Pakistan, but it is making vigorous efforts from its own level for women's rights. The currents of worldwide wave of women empowerment can now be felt in the big cities of Pakistan too. Definitely, the condition of women is pitiable in Pakistan not from the international standard of women's rights but also from the standards of developing countries. The most important positive factor is that women are awakening fast and raising their 
voices constantly to remove this dark shadow. Centuries old orthodox customs and traditions cannot be eliminated in one or two years. Melting of ice (problems related to woman community) has started but it will take long time to be realised in its ideal standard at the grass root level.

\section{References}

Al-Hashmi, Sayeed Abdullah (1983), Women in Islam: A Comparative Study, Islamic Publisher Ltd, Lahore, p.9.

Ali, M. Jrui. (1991), an Islamic and Western Values, Foreign Affairs, p. 119.

Alston, Margarate (2014), Women, Political Struggles and Gender Equality in South Asia

Anis, Ahmad (1981), Women and Social Justice, Institute of policy Studies, Islamabad, 80-81.

Anwar Saeed, (1984). Pakistan: Islam, Politics and National Solidarity, Vanguard, Lahore, 5-51.

Badbai J. (1999), The Status of Women in Islam, (Gailim, Saudi Arabia, p.6.

Bajwa, Malik (1981), Women in Islam, Advent Books, New York, p.2.

Javed (1988) Qur'an, Chapter 4, Stanza 19, the Rights of Women in Islam, 51. Martin Press, New York, p. 1.

Khawar Mumtaz and Farida Shaheed (1987), Women of Pakistan: Two Steps Forward, One Step Back, Zed Books.

Maududi, S.A.A (1993), Purdah and the Status of Women in Islam, Islamic Publication Ltd, Lahore, $154-155$

Rauf, M. Abdul (1981), The Islamic view of women and Family, Exposition press, New York, 10109.

Singh, Sudhir Kumar (2007), Human Rights in Pakistan, Pentagon Press.

V.R. and Sans, Viena Jones (Ed.) (1941), Women in Islam, Lucknow Publishing House, p 27.

Weiss. A (2014), Interpreting Islam, Modernity and Women's rights in Pakistan, Palgrave Macmillan US.

Yusuf and Mohammad, Kwadaya (1985), AI·Pam-Fl'-Sural Au-Niso. , Par-A1-Dawah. Kuwait, p. 15. 